\title{
ANALISIS KEMAMPUAN KONEKSI MATEMATIS SISWA DALAM MENYELESAIKAN MASALAH PADA MATERI PERBANDINGAN
}

\author{
Eka Hayu ${ }^{a}$, Rossa Linna ${ }^{b}$, Maimunah ${ }^{c}$, Yenita Roza ${ }^{d}$ \\ Pascasarjana Pendidikan Matematika Universitas Riau \\ Kampus Bina Widya KM 12,5 Simpang Baru Pekanbaru, \\ eka.hayu6520@grad.unri.ac.id,rossalinna6218@grad.unri.ac.id
}

\begin{abstract}
ABSTRAK
Koneksi matematis adalah kemampuan mengaitkan konsep-konsep matematika. Kemampuan tersebut membuat pengetahuan siswa lebih mendalam sehingga siswa dapat mengkaitkan konsepkonsep yang dapat digunakan dalam penyelesaian masalah. Tujuan penelitian ini adalah untuk mengetahui kemampuan koneksi matematis siswa SMP pada materi perbandingan. Penelitian ini merupakan penelitian deskriptif kualitatif. Teknik pengumpulan data yang digunakan adalah tes dan wawancara. Sampel terdiri dari 22 siswa kelas VIIB SMP Negeri 2 Salo. Hasil penelitian menunjukkan bahwa siswa mampu menghubungkan topik-topik antar matematika dengan persetase sebanyak 90,91\%, siswa mampu menggunakan matematika dalam pelajaran lain sebanyak $68,18 \%$, dan siswa mampu menggunakan matematika dalam kehidupan sehari-hari sebanyak 81,82\%. Kesimpulannya kemampuan koneksi matematis siswa kelas VII SMP tergolong tinggi. Implikasinya guru harus lebih kreatif merancang kegiatan pembelajaran yang dapat memfasilitasi kemampuan koneksi matematis siswa untuk lebih meninngkatkan memampuan koneksi matematis siswa pada setiap materi pembelajaran.
\end{abstract}

Kata Kunci : kemampuan koneksi matematis, perbandingan.

\begin{abstract}
Mathematical connection is the ability to associate mathematical concepts. This ability makes students' knowledge more profound so students can reach several aspects that can be used in problem solving. The purpose of this study was to determine the mathematical connection ability of middle school students in the comparison material. This research is a qualitative descriptive study. Data collection techniques used were tests and interviews. The sample consisted of 22 class VIIB students at SMP Negeri 2 Salo. The results showed that students were able to connect topics between mathematics with a percentage of $90.91 \%$, students were able to use mathematics in other lessons as much as $68.18 \%$, and students were able to use mathematics in everyday life as much as $81.82 \%$. In conclusion, the mathematical connection ability of class VII SMP students is high. The implication is that teachers must be more creative in designing learning activities that can facilitate students 'mathematical connection skills to increase the ability of students' mathematical connections to each learning material.
\end{abstract}

Keywords: mathematical connection ability, comparison. 


\section{Pendahuluan}

Matematika merupakan pelajaran yang bersifat hirarkis, konsep-konsep yang tingkatannya lebih tinggi dibentuk atas dasar konsep-konsep yang telah terbentuk sebelumnya. Matematika diperlukan setiap orang dalam kehidupan sehari-hari seperti berhitung, menghitung isi dan berat, menyajikan, mengolah dan menyimpulkan. Selain itu pada pelajaran lain seperti fisika, kimia, arsitek dan pelajaran lainnya matematika juga sangat diperlukan (Ekawati, 2011).

Keberhasilan dan kekurangan dalam pembelajaran mempengaruhi prestasi belajar siswa. Kekurangan dalam proses pembelajaran salah satu dilihat dari kesalahan siswa dalam menyelesaikan masalah matematis (Dikri, Hamidah, Nur, 2018). Selain itu Ansari (Hodiyanto, 2017) menyatakan bahwa terdapat beberapa hasil penelitian yang menunjukkan menurunnya pemahaman matematik siswa di kelas diantaranya: 1) pengajaran guru hannya mencontohkan pada siswa bagaimana menyelesaikan soal, 2) dalam pembelajara siswa hannya mendengar dan menonton guru melakukan matematik kemudian guru memecahkan sendiri, 3) dalam pembelajaran guru langsung menjelaskan topik yang akan dipelajari kemudian memberikan contoh dan soal untuk latihan. Hal ini menyebabkan tidak berkembangnya kemampuan koneksi matematis siswa.

Kemampuan koneksi matematis siswa rendah disebabkan siswa tidak dapat menerapkan konsep yang telah dipelajari sebelumnya dengan konsep yang terdapat pada materi yang akan dipelajari sehingga kesulitan dalam menyelesaikan soal (Warih, Parta, \& Rahardjo, 2016). Kemampuan koneksi matematis merupakan kemampuan yang dimiliki seseorang dalam menyajikan hubungan internal dan eksternal dari matematika seperti koneksi di antara topiktopik matematis, koneksi dengan ilmu yang lain, dan koneksi dengan kehidupan seharihari (Rohendi \& Dulpaja, 2013). Merujuk dari NCTM tahun 2000 menyebutkan bahwa terdapat lima kemampuan dasar matematika yang merupakan standar yakni pemecahan masalah, penalaran dan bukti, komunikasi, koneksi, dan representasi. Mengacu pada lima standar kemampuan NCTM, maka dalam tujuan pembelajaran matematika yang ditetapkan dalam Kurikulum 2006 yang dikeluarkan Permendiknas pada hakekatnya meliputi (1) koneksi antar konsep dan penggunaannya dalam memecahkan masalah, (2) penalaran, (3) pemecahan masalah, (4) komunikasi dan representasi, dan (5) faktor afektif (Arwinie, 2014). 
Mengingat terlalu banyak konsep dan prosedur matematika yang saling terpisah, koneksi matematis berperan penting dalam proses penyelesaian masalah matematika.

Kesadaran akan pentingnya koneksi matematis sangat penting. Apabila ditelaah tidak ada topic-topik dalam matematika yang berdiri sendiri tanpa adanya koneksi dengan topik lainnya. Untuk melatihnya anak harus mengalami dan mengikuti pembelajaran yang melatih koneksi matematis tersebut, salah satunya melalui pembelajaran yang bermakna. Koneksi proses-proses dan konsep-konsep terjadi dalam pikiran siswa, misalkan siswa menggunakan pikirannya pada saat menkoneksikan antara simbol dengan representasinya. Hal ini membuat pembelajaran siswa menjadi lebih bermakna.

Kemampuan koneksi matematis adalah kemampuan untuk mengaitkan konsep matematika yang satu dengan yang lain, dengan mata pelajaran lain dan dengan kehiduapan sehari- hari. Menurut NCTM (Linto, 2012) koneksi matematis terbagi dalam 3 aspek yang menjadi indikator koneksi matematis, yaitu: 1) koneksi antar topik dalam matematika, 2) koneksi dengan ilmu lain dan, 3) koneksi denga kehidupan sehari-hari. Dengan demikian matematika tidak hanya digunakan dalam matematika itu sendiri tetapi juga digunakan dalam ilmu lain dan dalam kehidupan nyata atau kehidupan sehari-hari siswa (Bernard, 2014).

Ketika siswa dapat memenuhi indikator-indikator koneksi matematis maka siswa dapat dengan mudah menghubungkan ide-ide matematika, pemahaman mereka lebih dalam dan lebih kekal. Melalui koneksi matematis antara suatu materi dengan materi lainnya siswa dapat menjangkau beberapa aspek untuk penyelesaian masalah. Tanpa koneksi matematis maka siswa harus belajar dan mengingat terlalu banyak konsep dan prosedur matematika yang saling terpisah. Saat ini masih saja terdapat siswa yang mengalami kesulitan dalam memahami dan menyelesaikan masalah matematika pada saat pembelajaran dikelas, meskipun guru telah menggunakan koneksi matematis. Menurut Bahr \& Garcia (2010) kesulitan koneksi matematis siswa adalah suatu hambatan yang dialami siswa dalam menyelesaikan soal, hambatan tersebut diantaranya hambatan dalam menghubungkan antara berbagai representasi serta konsep-konsep matematika secara internal ataupun secara eksternal, matematika dengan bidang lain baik mata pelajaran lain maupun dengan kehidupan sehari-hari.

Membangun pengetahuan dan keterampilan siswa diperlukan kemampuan 
koneksi matematis sehingga kemampuan itu harus diterapkan dalam pembelajaran selain itu, koneksi matematis juga erat kaitannya dengan kehidupan sehari-hari (Islamiah, 2018). Dengan menghubungan antar topik atau pokok bahasan dalam matematika dan mengaitkan matematika dengan dengan ilmu lain ataupun dengan kehidupan sehari-hari maka siswa tersebut dikatakan memiliki kemampuan koneksi matematis (Hadin, Pauji, dan Aripin, 2018).

Berdasarkan uraian di atas peneliti tertarik untuk meneliti tentang kemampuan koneksi matematis siswa SMP. Tujuan penelitian ini adalah untuk mengetahui kemampuan koneksi matematis siswa pada materi perbandingan. Pemilihan materi teorema pythagoras dikarenakan materi tersebut sangat penting dalam pembelajaran matematika di sekolah. Selain itu materi tersebut memuat banyak koneksi matematis dengan materi lainnya. Dengan diketahuinya gambaran kemampuan koneksi matematis siswa, diharapkan dapat digunakan sebagai bahan pertimbangan guru dalam memilih strategi pembelajaran yang dapat meningkatkan kemampuan koneksi matematis siswa. Selain itu, dapat menjadi acuan guru dalam membiasakan siswa mengenal dan menerapkan koneksi matematis dalam menyelesaikan masalah, khususnya pada materi perbandingan.

\section{Metode Penelitian}

Penelitian ini merupakan penelitian deskriptif dengan menggunakan pendekatan kualitatif. Penelitian ini dilaksanakan di SMP Negeri 2 Salo yang berada di Jl. Datuk Harunsyah Desa Siabu Kecamatan Salo Kabupaten Kampar. Subjek dari penelitian yaitu siswa kelas VII B sebanyak 22 siswa. Materi yang digunakan yaitu materi perbandingan

Teknik pengumpulan data yang digunakan pada penelitian ini adalah dengan wawancara dan tes yang diberikan kepada siswa. Data yang dikumpulkan dalam penelitian ini adalah data koneksi matematis yang diperoleh pada saat siswa mengerjakan soal yang telah dibuat berdasarkan indikator koneksi matematis dan dalam wawancara. Hasil wawancara yang digunakan merupakan data pendukung selain hasil tes koneksi matematis. Menurut Creswell hasil wawancara merupakan data kualitatif yang berupa jawaban atau pendapat atas pertanyaan yang diajukan oleh si pewawancara (Creswell, 2013). Dalam penelitian ini, peneliti merupakan instrumen utama yang bertindak sebagai pengumpul, 
analisator, penafsir dan pelapor hasil penelitian (Moleong, 2017).

Indikator soal koneksi matematis yang digunakan dalam penelitian ini yaitu menentukan hubungan antar topik matematika, menggunakan matematika dalam pelajaran lain, dan menggunakan matematika dalam kehidupan sehari-hari (Afifah, 2017). Pedoman penskoran kemampuan koneksi matematis yang digunakan merupakan modifikasi dari sumarmo, 2016:

Tabel 1. Pedoman Penskoran Kemampuan Koneksi Matematis Siswa

\begin{tabular}{cl} 
Skor & \multicolumn{2}{c}{ Kriteria } \\
$\mathbf{0}$ & Tidak ada jawaban \\
$\mathbf{1}$ & $\begin{array}{l}\text { Jawaban tidak sesuai dengan } \\
\text { pertanyaan }\end{array}$ \\
$\mathbf{2}$ & $\begin{array}{l}\text { Ada beberapa jawaban yang sesuai } \\
\text { dengan pertanyaan tetapi koneksinya }\end{array}$ \\
& $\begin{array}{l}\text { tidak jelas } \\
\text { Ada beberapa jawaban yang sesuai } \\
\text { dengan pertanyaan dan koneksinya }\end{array}$ \\
$\mathbf{4}$ & $\begin{array}{l}\text { jelas tetapi tidak lengkap } \\
\text { Jawaban sesuai dengan pertanyaan }\end{array}$ \\
$\mathbf{5}$ & $\begin{array}{l}\text { Jawaban sesuai dengan pertanyaan dan } \\
\text { lengkap }\end{array}$ \\
\end{tabular}

Tabel 2. Kategori Kemampuan Koneksi Matematis Siswa

$\begin{array}{cc}\text { Kategori } & \begin{array}{c}\text { Pencapaian Kemampuan } \\ \text { Koneksi }\end{array} \\ \text { Tinggi } & 70 \leq \mathrm{KKN}<100 \\ \text { Sedang } & 50 \leq \mathrm{KKN}<70 \\ \text { Rendah } & 0 \leq \mathrm{KKN}<50\end{array}$

Setialesmana, Anisa, dan Herawati, (2017).

Prosedur yang digunakan dalam penelitian ini meliputi tahap perencanaan yaitu menyusun soal tes koneksi matematis dan pedoman wawancara. Tes merupakan alat untuk mengumpulkan suatu informasi tentang karakteristik suatu objek (Widoyoko, 2012). Tes dilakukan dengan tujuan untuk mengetahui jawaban siswa dalam menyelesaikan masalah bangun kesebangunan. Soal tes yang disusun diperoleh dari soal ujian nasional atau UN yang berkaitan dengan materi perbandingan dan sesuai dengan indikator kemampuan koneksi matematis siswa. Soal ujian nasional dipilih karena sudah valid dan memiliki reliabilitas yang baik. Sedangkan wawancara yang dilakukan untuk mendapatkan informasi yang lebih jelas dari siswa yang menjadi subjek penelitian yang tidak dapat diungkapkan secara tertulis ketika siswa menjawab soal tes koneksi matematisyang diberikan peneliti. Wawancara dilaksanakan setelah pelaksanaan tes dan dilakukan secara perindividu. Tahap selanjutnya dalam penelitian ini adalah pengumpulan data. Data yang terkumpul kemudian dianalisis dengan analisis kualitatif

\section{Hasil dan Pembahasan}

Tes kemampuan koneksi matematis dalam penelitian ini terdiri dari 3 soal yang berbentuk uraian sesuai dengan indikator soal koneksi matematis. Penilaian tiap butir 
soal berdasarkan pedoman penskoran Setialesmana, Anisa, dan Herawati, (2017). Data kemampuan koneksi matematis yang diperoleh dari hasil tes siswa dapat dilihat pada tabel 3 .

Tabel 3. Hasil Tes Kemampuan Koneksi Matematis

$\begin{array}{ccccc}\begin{array}{c}\text { No } \\ \text { Soa } \\ \mathbf{l}\end{array} & \begin{array}{c}\text { Skor } \\ \text { Maksim } \\ \text { al }\end{array} & \begin{array}{c}\text { Jumla } \\ \text { h } \\ \text { Siswa } \\ \text { Benar }\end{array} & \begin{array}{c}\text { Persenta } \\ \text { se }\end{array} & \begin{array}{c}\text { Katego } \\ \text { ri }\end{array} \\ \mathbf{1} & 5 & 20 & 90,91 \% & \\ \mathbf{2} & 5 & 15 & 68,18 \% & \text { Tinggi } \\ \mathbf{3} & 5 & 18 & 81,82 \% & \text { Tinggi }\end{array}$

Pada indikator kemampuan koneksi matematis dilihat pada soal nomor 1 yaitu menghubungkan materi antar topik matematika. Soal diambil dari soal ujian nasional tahun 2017. Soal nomor 1: Perbandingan umur Rahma, Fadila, dan Taufik berturut-turut $8: 3: 10$. Jika selisih umur Rahma dan Taufik adalah 4 tahun, maka jumlah umur mereka bertiga adalah. Berikut tampilan jawaban siswa pada soal tes nomor 1

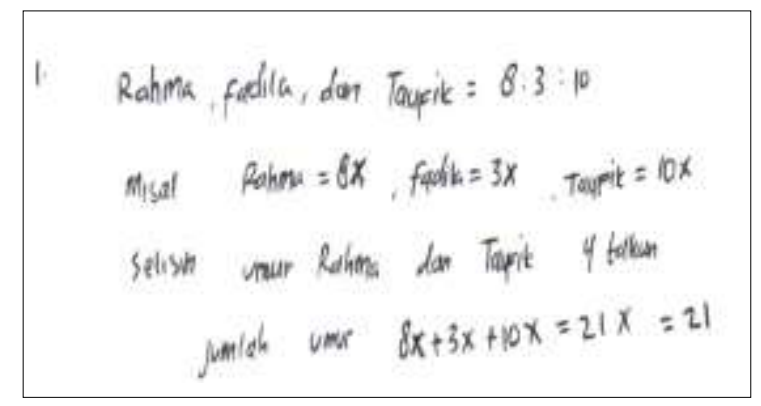

Gambar 1. Jawaban siswa nomor 1

Pada soal nomor 1, siswa diminta menentukan jumlah umur dengan menghubungkan konsep perbandingan dengan sistem persamaan linier satu variabel. Berdasarkan hasil analisis sebanyak 90,91\% siswa dapat menjawab dengan benar. Indikator nomor 1 tergolong tinggi terbukti 20 siswa menyelesaikannya.

Berdasarkan hasil wawancara dengan beberapa siswa yang menjadi subjek penelitian, pada soal nomor 1 siswa yang salah sebanyak 2 orang dengan kesalahan yang sama yaitu tidak menentukan nilai variabel yang dimisalkan sehingga salah pada hasil akhirnya. Ketika dilakukan wawancara diperoleh bahwa kedua siswa tersebut sudah memahami hubungan atau koneksi antar matematika dengan memisalkan sebuah variabel $\mathrm{x}$ pada jawabannya hanya saja siswa tersebut belum menentukan nilainya. Berdasarkan hal tersebut bahwa indikator soal nomor satu berhasil secara keseluruhan. Adapun untuk soal nomor 2 siswa diminta untuk menentukan perbandingan kecepatan mobil dan pejalan kaki. Soal ini mengungkap kaitan antara materi matematika yaitu perbandingan dengan materi fisika yaitu kecepatan. Soal diambil dari ujian nasional tahun 2018. Soal nomor 2: Dengan mobil jarak $120 \mathrm{~km}$ dapat ditempuh dalam waktu 2 jam, sedangkan dengan jalan kaki jarak 100 meter dapat ditempuh dalam waktu 2 menit. 
Perbandingan kecepatan mobil dan jalan kaki adalah. Berikut tampilan jawaban siswa soal nomor 2

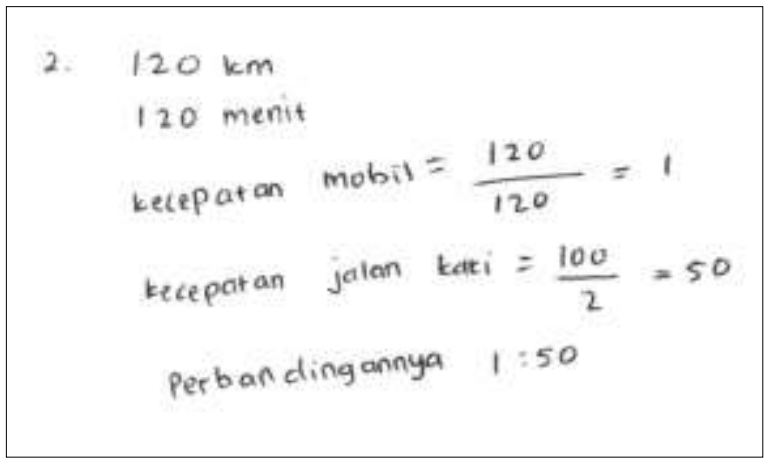

Gambar 2. Jawaban siswa nomor 2 siswa 1

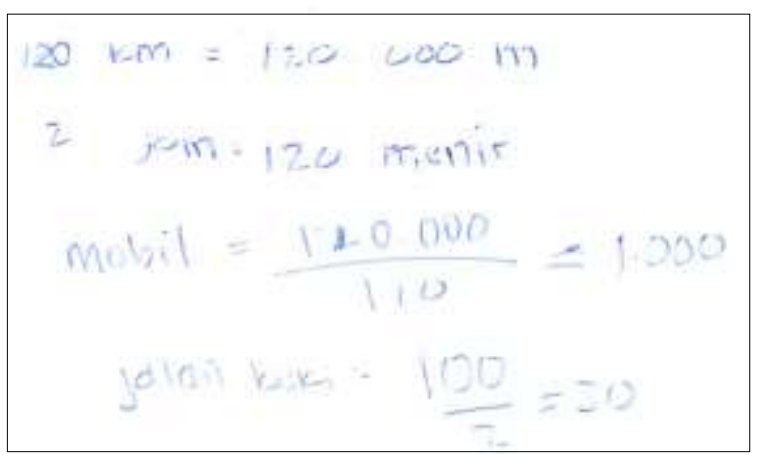

Gambar 3. Jawaban siswa nomor 2 siswa 2

Pada soal nomor 2, sebagian besar siswa mampu berfikir dengan menggunakan matematika dalam pelajaran lain. Soal ini menguji kemampuan siswa dalam menggunakan matematika dengan fisika pada materi kecepatan. Terlihat $68,18 \%$ pada persentase indikator soal 2 kategori sedang.

Sebanyak 15 siswa yang menjawab dengan benar dan 7 siswa menjawab kurang tepat. Berdasarkan hasil wawancara dengan siswa yang melakukan kesalahan diperoleh bahwa sebagian besar siswa dapat menggunakan matematika dalam pelajaran lain hannya salah pada pengubahan satuan. Ada juga siswa yang melakukan kesalahan dengan tidak menggunakan koneksi matematisnya dalam menggunakan materi kecepatan dengan perbandingan. Ini berarti koneksi matematis untuk indikator soal 2 tergolong sedang.

Pada indikator menggunakan matematika dalam kehidupan sehari-hari dapat dilihat pada soal nomor 2. Soal diambil dari soal ujian nasional tahun 2018. Soal nomor 3: Perbandingan uang Verrel, Saffa, dan Mahesa $4: 3$ : 2. Jika jumlah uang Verrel dan uang Saffa Rp 42.000,00, maka jumlah uang mereka bertiga adalah. Berikut contoh jawaban siswa pada soal nomor 3 .

$$
(4+3+2) \times 42000=370000
$$

Gambar 4. Jawaban siswa nomor 3

Pada soal nomor 3 siswa dapat menyelesaikan soal dengan baik dan benar terlihat dari persentase yang didapat sebesar $81,82 \%$ kategori tinggi. Siswa dapat menggunakan matematika dalam kehidupan sehari-hari. Hal ini terlihat dari 22 siswa kelas VIIB sebanyak 18 siswa menjawab dengan benar dan hannya 4 siswa yang menjawab kurang tepat, tetapi untuk keseluruhan siswa sudah bisa menggunakan matematika dalam kehidupan sehari-hari. Kesalahan dari keempat siswa lebih banyak 
dikesalahan dalam memahami dan memaknai soal, sehingga mereka kurang tepat menjawabnya.

Pada soal nomor 3 diperoleh bahwa hampir seluruh siswa dapat menyelesaikan soal dengan benar. Hasil wawancara diperoleh bahwa siswa sudah bisa menggunakan matematika dalam kehidupan sehari-hari. Ketika ditanya kebanyakan siswa dapat menjawab dengan jawaban yang tepat.

Berdasarkan hasil wawancara dapat disimpulkan bahwa dari keseluruhan soal yang diberikan siswa kelas VII SMP Negeri 2 Salo dapat menyelesaikan soal dengan baik sehingga kemampuan koneksi matematis siswa dikategorikan tinggi. Siswa yang kurang tepat menjawab saat tes tetapi bisa menjelaskan pada saat wawancara maka siswa tersebut tergolong dapat memenuhi indikator yang dituju.

Faktor-faktor yang mempengaruhi tinggi rendahnya kemampuan koneksi matematis yang dimiliki siswa pada menghubungkan topik antar matematika yaitu siswa kurang memahami tentang materi satuan dan operasi hitung yang kurang tepat sehingga siswa masih salah dalam merubah satuan dan melakukan operasi baik penjumlahan, pengurangan, perkalian, bahkan pembagian. Hal ini menunjukkan bahwa siswa harus menguasai materi prasyarat dengan baik. Aspek koneksi matematika dengan pelajaran lain: siswa belum seluruhnya paham kaitan materi perbandingan dengan fisika (kecepatan), siswa sedikit kesulitan menghubungi materi yang telah dipelajari dengan materi kecepatan. Aspek koneksi dengan kehidupan sehari-hari: Siswa sudah bisa melihat penggunaan matematika dalam kehidupan sehari-hari walaupun masih ada pengerjaan siswa yang kurang tepat operasinya.

\section{Simpulan}

Berdasarkan hasil analisis dan pembahasan, maka dapat disimpulkan bahwa kemampuan koneksi siswa SMP tergolong tinggi. Hal ini terlihat dari hasil keseluruhan kemampuan koneksi matematis yang diperoleh siswa sebesar 80,30\% masuk pada kategori tinggi dari pengerjaan soal-soal koneksi matematis.

Hasil penelitian ini diharapkan dapat memberikan informasi kepada pihak sekolah terutama guru bidang studi matematika mengenai kemampuan koneksi matematis siswa sehingga dapat menjadi acuan guru menerapkan koneksi matematis untuk menyelesaikan soal. Mengingat pentingnya koneksi matematis dan fakta mengenai kemampuan koneksi matematis siswa, diharapkan guru mampu merancang kegiatan 
pembelajaran yang dapat memfasilitasi kemampuan koneksi matematis siswa.

\section{Pustaka}

Afifah, Rima Nur. (2017). Kemampuan Koneksi Matematis Pada Bangun Ruang Sisi Lengkung. Seminar Matematika dan Pendidikan Matematika UNY. M-90

Arwinie, N. 2014. Meningkatkan Kemampuan Penalaran Dan Komunikasi Matematis Serta SelfConcept Siswa MTS Melalui Pembelajaran Berbasis Masalah. Skripsi. Bandung: Universitas Pendidikan Indonesia.

Azis, Dikri Maulana, Hamida, Nur. (2018). Analisis Kesalahan Siswa dalam Menyelesaikan Soal Matematika pada Materi Sistem Persamaan Linear Tiga Variabel Kelas X SMAN 1 Cisaat. Jurnal Tadris Matematika. 1(2), 193-206.

Bahr, D. L \& Garcia, L. A. (2010). Elementary Mathematics is Anything But Elementary: Content and Methods From a Development Perspective. USA: Wadsworth, Cengage Learning.

Bernard, M. (2014). Meningkatkan Kemampuan Penalaran Matematik Siswa SMA Melalui Game Adobe Flash CS 4. In Prosiding Seminar Nasional Pendidikan Matematika (Vol. 3, pp. 205-213).

Creswell, J. W. (2013). Educational Research: Planning, Conducting, and Evaluating Quantitative and Qualitative Research. Journal of
Chemical Information and Modeling.

Ekawati, Shindy. (2011). Deskripsi Kemampuan Koneksi Matematis Siswa Pada Materi Pythagoras Kelas VIII SMP Negeri 4 Lamasi Ditinjau Dari Gaya Kognitif. Pedagogy. Vol. 3, No. 2.

Hadin, H., Pauji, H. M., \& Aripin, U. (2018). Analisis Kemampuan Koneksi Matematik Siswa MTS Ditinjau Dari Self Regulated Learning. JPMI (Jurnal Pembelajaran Matematika Inovatif), 1(4), 657-666.

Hodiyanto. (2017). Kemampuan Komunikasi Matematis dalam Pembelajaran Matematika. Jurnal Admathedu. Vol. 7, No. 1, 10-11.

Islamiah, N., Purwaningsih, W. E., Akbar, P., \& Bernard, M. (2018). Analisis Hubungan Kemampuan Pemecahan Masalah Matematis dan Self Confidence Siswa SMP. Journal on Education, 1(1), 47-57.

Linto, R. L., Elniati, S., \& Rizal, Y. (2012). Kemampuan Koneksi Matematis Dan Metode Pembelajaran Quantum Teaching Dengan Peta Pikiran. Jurnal Pendidikan Matematika, Part 2, Vol. 1 No. 183-87.

Moleong, L. J. (2017). Metodologi Penelitian Kualitatif (Edisi Revisi). In PT. Remaja Rosda Karya.

Rohendi, D., \& Dulpaja, J. (2013). Connected Mathematics Project (CMP) Model Based on Presentation Media to the Mathematical Connection Ability of Junior High School Student. Journal of Education and Practicetice. 
Setialesmana, D., Anisa, W. N., \& Herawati, L. (2017). Asosiasi Kemampuan Koneksi Dan Komunikasi Matematik Mahasiswa Melalui Metode Inkuiri Model Alberta. Jurnal Siliwangi Seri Pendidikan, 3(2).

Sumarmo, U. (2016). Pedoman Pemberian Skor pada Beragam Tes Kemampuan Matematik. Kelengkapan Bahan Ajar Mata Kuliah Evaluasi Pembelajaran Matematika pada Program Magister Pendidikan Matematika STKIP Siliwangi: Tidak diterbitkan.

Warih, P. D., Parta, I. N., \& Rahardjo, S. (2016). Analisis kemampuan koneksi matematis siswa kelas VIII pada materi teorema Pythagoras. Prosiding Konferensi Nasional Penelitian Matematika Dan Pembelajarannya [KNIP I], (Knpmp I), 377-384. Retrieved from http://hdl.handle.net/11617/6978

Widoyoko, Eko Putro. (2012). Teknik Penyusunan Instrumen Penelitian. Yogyakarta: Pustaka Pelajar. 